\title{
Husserl's Conception of Experiential Justification: What It Is and Why It Matters
}

\author{
Philipp Berghofer ${ }^{1}$ (D)
}

Published online: 13 February 2018

(C) The Author(s) 2018. This article is an open access publication

\begin{abstract}
The aim of this paper is twofold. The first is an interpretative one as I wish to provide a detailed account of Husserl's conception of experiential justification. Here Ideas I and Introduction to Logic and Theory of Knowledge: Lectures $1906 / 07$ will be my main resources. My second aim is to demonstrate the currency and relevance of Husserl's conception. This means two things: Firstly, I will show that in current debates in analytic epistemology there is a movement sharing with Husserl the basic idea that certain experiences gain their justificatory force simply from their distinctive phenomenal character. Secondly, I shall reveal the benefits of Husserl's specific version of this view. Thus, one of my aims is to show that debates in current analytic epistemology could profit from adopting certain Husserlian elements. More precisely, I will defend Husserl's claim that perceptual experiences are justifiers due to their self-giving phenomenal character as opposed to the currently popular view that it is the phenomenology of pushiness that makes them justifiers. To put it differently, what matters is what is originally given within experience and not how you feel about what is given.
\end{abstract}

\section{Husserl's Notion of Intuition and Some Epistemological Principles}

Thanks to the works of phenomenologists such as Dan Zahavi, David Woodruff Smith, and John Drummond, Husserl's phenomenology plays a considerable role in current philosophy of mind. In current epistemology, however, the situation is quite different. Although Husserl's phenomenology, especially his conception of intuition, offers a lot to enrich current debates on, for instance, epistemic

Philipp Berghofer

philipp.berghofer@uni-graz.at

1 Department for Philosophy, University of Graz, Heinrichstraße 26/6, 8010 Graz, Austria 
justification, evidence, moral perception, and moral intuition, there is, unfortunately, no noticeable Husserlian impact on the treatment of these issues in current analytic philosophy. It is one of the aims of this paper to serve as a starting point for changing this situation and for re-evaluating the relevance of Husserl for current analytic epistemology. The purpose of this paper, to be sure, is not to convince someone who champions a view radically different from Husserl's to become a Husserlian-style epistemologist. Rather, the purpose is (1) to give a detailed account of Husserl's conception of experiential justification, (2) to show that in current analytic epistemology there is a movement sharing with Husserl the basic idea that certain experiences gain their justificatory force simply from their distinctive phenomenal character, and (3) to highlight the advantages of Husserl's specific version of such a phenomenological conception of experiential justification. Between phenomenology and current analytic epistemology, there is a great potential of rich and mutually beneficial synergies, which is why phenomenologists should engage in current debates. Thus, in a nutshell, the objective of this paper is to reveal what a phenomenological conception of experiential justification looks like and how Husserl's specific version of such a conception is in some aspects superior to current alternative versions.

Husserl's phenomenological conception of experiential justification offers a novel and promising approach towards epistemic justification whose ingenuity, unfortunately, is often overlooked by commentators. By closely connecting epistemology and philosophy of mind, Husserl argues for the following four theses which might be regarded as the cornerstones of a Husserlian conception of experiential justification.

E1: Justification-conferring experiences such as perceptual experiences exhibit the phenomenal character of originary givenness.

E2: Originary presentive intuitions are a source of immediate justification.

E3: Originary presentive intuitions are the ultimate source of justification.

E4: Originary presentive intuitions are a source of justification precisely in virtue of their phenomenal character of originary givenness.

That epistemology and philosophy of mind are intertwined in the sense that the fundamental epistemic principles are phenomenological principles in the spirit of E1-E4, expressing the basic idea that epistemic justification is determined by the phenomenal character of experiences, is a distinctively phenomenological claim and has been largely ignored or dismissed by contemporary analytic epistemology. ${ }^{1}$ Only very recently have certain philosophers in this tradition picked up this idea, as we shall see at the end of this paper. ${ }^{2}$ Especially E4 is a rather strong claim and it is the aim of this paper to show (1) that Husserl subscribes to E4 and (2) that current

\footnotetext{
1 To be fair, however, phenomenologists have also largely failed to make claims such as E1-E4 explicit, to develop them systematically, and to highlight their benefits by engaging with rival views. One of the rare occasions of a current phenomenologist explicitly interpreting Husserl as subscribing to E4 is Erhard (2012, p. 56, fn 25).

2 Among the few analytic philosophers who argue for closely connecting epistemology and philosophy of mind similarly to how it is proposed in the present paper is Declan Smithies whose (2014) convincingly highlights some of the benefits of such a close connection.
} 
debates in analytic epistemology could benefit from adopting E4. But first things first. So, what are originary presentive intuitions?

Originary presentive intuitions are intentional acts in which the object/content is presented as "bodily present" (Hua XVI, p. 14), is given in a "fleshed out" manner (Hua XIX/1 1984, p. 458). These acts are contrasted with empty, signitive acts in which what is given to us is not the object in its actual presence but the object as something that is meant only (cf. especially Husserl's Sixth Logical Investigation). The prime example of originary presentive acts are perceptual acts in which we are perceptually aware of the object in question. ${ }^{3}$ If you believe that there is a table in the room next to you, this belief is a signitive act. If you go and check and see the table, this perceptual experience is an intuitive act.

Two clarifications are in order. First, Husserl uses the term "originary intuition" in a remarkably broad sense. Straightforward sense experiences of physical objects, categorial intuitions of states of affairs, essential intuitions of logical, or mathematical, or phenomenological truths, and introspective intuitions of one's own mental states are all originary presentive intuitions. ${ }^{4}$ In his mature theory of value, Husserl insists that even value-ceptions (Wertnehmungen) are originary presentive acts (Hua XXX 1996, p. 287). ${ }^{5}$ Secondly, according to my reading, hallucinations and illusions can also be originary intuitions. ${ }^{6}$ This is important because if you have a perfect hallucination of a table in front of you, you are plausibly justified in believing that there is a table.

In his "Principle of all Principles" (Ideas I, §24) Husserl leaves no doubt about the central role of intuition ${ }^{7}$ :

No conceivable theory can make us err with respect to the principle of all principles: that every originary presentive intuition is a legitimizing source of cognition, that everything originarily (so to speak, in its "personal" actuality) offered to us in "intuition" is to be accepted simply as what it is presented as being, but also only within the limits in which it is presented there. (Hua III/1, p. $51 ; 1982$, p. 44)

\footnotetext{
${ }^{3}$ An anonymous referee of this journal has rightfully pointed out that while it is true that for Husserl perceptual acts are the prime examples of originary presentive acts, this by no means implies that there is only one type of evidence. In his doctrine of the correlational a priori, Husserl links different types of evidence to different types of objects. Husserl distinguishes between inadequate, adequate, and apodictic evidence. According to my understanding, different types of evidence correspond to different types of originary givenness. We will briefly discuss this at the end of the paper.

${ }^{4}$ There are different types of originary intuition and these different types of intuition correspond to different types of objects. This means that "the precise nature of the intuitive evidence at issue varies in dependence on the respective types of objects or states of affairs that the relating acts are directed towards." (Rinofner-Kreidl 2014, p. 37).

${ }^{5}$ Which means that the present paper has also crucial implications for meta-ethics. For the details and significance of a phenomenological intuitionism cf. Rinofner-Kreidl (2015).

${ }^{6}$ For the claim that hallucinations also are (originary) intuitions cf. Erhard (2012, p. 57), who confirms this by referring to Hua XVI, p. 15.

${ }^{7}$ In the present paper, whenever I use the term "intuition" what I mean is "originary presentive intuition." This means that, in contrast to Husserl's terminology, imaginative acts, for instance, do not count as intuitions. Imaginative acts are not originary presentive intuitions because, when I imagine an object $\mathrm{O}, \mathrm{O}$ is not given in its actual presence. Note that this is only a terminological issue.
} 
While this passage unambiguously reveals the importance of intuition, it seems problematic that Husserl here talks about "cognition" instead of justification. Furthermore, this passage does not indicate why intuitions have justificatory force. What it is that makes intuitions justifiers? The passage of Ideas I that best encapsulates Husserl's main epistemological principles with respect to intuition is the following one:

Immediate "seeing", not merely sensuous, experiential seeing, but seeing in the universal sense as an originally presentive consciousness of any kind whatever, is the ultimate legitimizing source of all rational assertions. This source has its legitimizing function only because, and to the extent that, it is an originally presentive source. [...] Moreover, as may be added here to prevent possible misinterpretations, that does not exclude the possibility that, under some circumstances, one seeing conflicts with another and likewise that one legitimate assertion conflicts with another. For that, perhaps, no more implies that seeing is not a legitimizing basis than the outweighing of one force by another signifies that the outweighed force is not a force. It does say, however, that perhaps in a certain category of intuitions (and that is the case precisely with sensuously experiencing intuitions) seeing is, according to its essence, "imperfect," that of essential necessity it can become strengthened or weakened, that consequently an assertion having an immediate, and therefore genuine, legitimizing ground in experience nevertheless may have to be abandoned in the further course of experience because of a counter legitimacy outweighing and annulling it. (Hua III/1, p. 43; 1982, p. 36f.)

From the context it is clear that "immediate 'seeing"" is synonymous with originary intuition. Let us try to summarize Husserl's epistemological principles that can be derived from this passage.

P1: Intuitions are a source of immediate justification. ${ }^{9}$

P2: Intuitions are the ultimate source of justification.

P3: Intuitions are fallible. ${ }^{10}$

P4: Intuitions are cases of immediate seeing that exhibit the distinctive feature of having an originally presentive phenomenal character, which means that they give their objects/contents in an originally presentive way.

\footnotetext{
${ }^{8}$ For why this might be problematic, see Berghofer (2017, Section 2.2) and Hopp (2016).

9 A belief of yours is immediately (i.e., non-inferentially) justified if this belief is epistemically independent of your other beliefs. There is no need for epistemic support by your other beliefs. Such a noninferentially justified belief is a basic belief. A basic experiential belief is a belief that is non-inferentially justified by an experience. We can say: An experience E provides immediate justification for believing proposition $p$ if having $\mathrm{E}$ is sufficient for justifiably believing that $p$. In order to be justified, the belief that $p$ is not in need of epistemic support of anything other than the underlying experience E. It has been argued that Husserl's conception of horizonal intentionality and the fact that he acknowledges the epistemic force of coherence show that Husserl does not allow for immediate justification and in further consequence that he cannot be considered a foundationalist. I have refuted such claims in Berghofer (2017). Moderate foundationalist systems can allow for incorporating coherentist elements, and Husserl's conception of horizonal intentionality concerns the structure of experience, not the structure of justification.

10 Strictly speaking, this passage only indicates that perceptual intuitions are fallible. For a commitment to the fallibility even of essential intuitions cf. Hua XVII (1974, p. 164) and Hua XXV (1987, p. 248).
} 
P5: "Seeing" is to be understood in a very broad sense and is not restricted to the scope of sensibility. Physical objects as well as, for example, ideal objects can be given intuitively.

P6: Intuitions are experiences which gain their justificatory force from their distinctive - namely, originally presentive - phenomenal character.

This enumeration, surely, is by no means complete, but it captures what I am mainly concerned with. P1 and P2 make Husserl a foundationalist; ${ }^{11}$ P1-P3 make him a moderate foundationalist. ${ }^{12} \mathrm{P} 4$ and $\mathrm{P} 5$ shed some light on what intuitions are meant to be, and P6 tells us what it is that makes intuitions justifiers - their distinctive, justification-conferring phenomenal character. Our focus in this paper is on P6.

Before I turn to the next section to elaborate on P6 in more detail, I would like to discuss a possible objection to my claim that for Husserl it is originary intuitions that carry justificatory force. In his sublime article, Walter Hopp has recently argued that it is not the intuitive acts but the fulfillments that justify our beliefs. "The important point is that it is fulfillment, not mere intuition, that justifies." (Hopp 2016, p. 185) Fulfillment takes place when a full intention matches a corresponding empty intention, i.e., when the object is intuitively given as it is emptily intended. Fulfilling acts are intuitive acts that fulfill empty intentions. Thinking about a table in the room next to you, believing or wishing that there is a table in the room next to you, all are signitive acts. When you go and check and have a visual experience of a table, this act is an intuitive act that fulfills your signitive acts.

However, I disagree with Hopp's claim that only fulfillments can justify, as I hold that even intuitive acts which are in disagreement with their corresponding signitive acts have justificatory force. Suppose you strongly believe that your door is closed. To be sure, you go and check and see that the door is open. This act of seeing is an intuitive act that is in disagreement with your signitive act of believing, but surely this act of seeing has justificatory force. One might object that in such a case this act of seeing fulfills a different, new signitive act that is caused by your experience.

\footnotetext{
${ }^{11}$ Foundationalism is a theory about the structure of justification, according to which, all justified beliefs are either non-inferentially justified or epistemically dependent upon such non-inferentially justified beliefs. Since Husserl argues that intuitions are not only a source of immediate justification but also the ultimate source of justification, he qualifies as a foundationalist. Of course, there exist many different versions of foundationalism. Foundationalist systems can differ in what they consider to be the ultimate justifiers, what they understand by inferential justification, whether they allow for the fallibility of justification, and whether they allow that also coherence can play an epistemically significant role. In Berghofer (2017) I have argued that Husserl's version of foundationalism is the most tenable version of foundationalism.

${ }^{12}$ Moderate is any version of foundationalism that allows that immediate justification can be fallible (BonJour 1985, p. 26). Traditionally, foundationalism has been associated with strong foundationalism, i.e., foundationalism that demands that immediate justification must be infallible, the most notable example being Descartes' foundationalism. BonJour rightly complains that " $[\mathrm{m}]$ ost historical discussions of foundationalism and even many quite recent ones, both pro and con, have focused almost exclusively on strong foundationalism." (BonJour 1985, p. 27) Furthermore, it is often wrongfully assumed that foundationalist systems cannot incorporate coherentist elements. But note that foundationalists only must deny that coherence of beliefs is necessary or sufficient for justification. There is no systematic reason why foundationalists should deny that (even basic) beliefs can gain justificatory support from coherence with other beliefs. For the details of Husserl's version of moderate foundationalism cf. Berghofer (2017, Section 2.3).
} 
This seems to be Hopp's position. Fulfillment is necessary because it conceptualizes our non-conceptual intuitions. ${ }^{13}$ However, I believe that Hopp has to agree that intuitions have justificatory force even if for Hopp it is only fulfillment that actually justifies. $^{14}$

I shall conclude this section by briefly addressing the relationship between perception and judgment. Husserl clearly distinguishes between perception and (perceptual) judgment (cf. Hua XIX/2 1984, p. 556) as well as between perceptual sense and perceptual statement or judgment-sense (cf. Hua XX/1 2002, p. 71). The perceptual judgment (Wahrnehmungsurteil) is based on the perceptual experience. The perceptual statement (Wahrnehmungsaussage) expresses "what is given in perception" (Hua XX/1 2002, p. 70). Importantly, Husserl points out that the perceptual judgment must not go beyond what is given within experience. Husserl gives the following example: If you have an indistinct perceptual experience of something black that moves and, based on this perceptual experience, you judge, "A blackbird flies up," this judgment is not really a perceptual judgment (Hua XX/1 2002 , p. 71). This is because the judgment goes beyond what is given in perception, it is not part of the perceptual sense. In this case, a truly perceptual judgment would have been, "Something black moves." (Hua XX/1 2002, p. 71) Thus, perceptual sense and perceptual judgment are intrinsically connected. ${ }^{15}$ However, for Husserl, it is clear that perception cannot be identified with judgment since the same perceptual experience can be expressed by many different perceptual judgments and in most cases the perceptual sense clearly goes beyond the judgment-sense (Hua XIX/2 1984, p. 550). The perceptual sense or content is, so to speak, richer than the judgment.

Whether Husserl considers perceptual content to be conceptual or not is a much debated question I do not want to address in this paper. Two things, however, are of particular significance for the present paper. Firstly, perception is distinct from judgment. Secondly, perception can immediately justify judgments. Note that these points are connected. If perception is itself a judgment, it seems that perception is in need of justification. If perceiving a laptop means judging that there is a laptop, the question arises, what is the justifier for this judgment. This is why many current epistemologists stress that perceptual experiences are distinct from beliefs/judgments and that thus immediate justification is possible and the threat of an infinite

\footnotetext{
${ }^{13}$ Note that if this is true, then fulfillment is a necessary condition for having a justified belief. (This is because conceptualization is necessary for believing.) I am not in disagreement with this. My point merely is that being a full intuition, i.e., exhibiting the phenomenal character of originary givenness, is a sufficient condition for carrying justificatory force. A more detailed analysis might reveal that the main difference between Hopp and me is that he is primarily concerned with doxastic justification while I am with propositional justification.

${ }^{14}$ To be sure, I do not want to downplay the epistemic significance of fulfillments. Possibilities of fulfillments, which are themselves determined by the type of object that is intuited, determine possible types (inadequate, adequate, apodictic) of evidence and possible degrees and further characteristics (e.g., non-inferential vs. inferential) of justification (this is, basically, what Husserl's doctrine of the correlational a priori reveals).

${ }^{15}$ Husserl says that "in perceptual judgments the perception is in an inner relation to the signifying [Bedeuten] of the statement such that the sense of latter "lies' somehow in the perception." (Hua XX/1 2002, p. 70).
} 
regress avoided (Ghijsen 2016, p. 37f.). ${ }^{16}$ Perception justifies but is not in need of justification (cf. Hua XXIV, p. 8 and Huemer 2001, p. 97). ${ }^{17}$

\section{Husserl's Conception of Experiential Justification}

There is little doubt that there is experiential justification, i.e., justification provided by experiences. My perceptual experience of a black laptop in front of me, my logical intuition that $\sim(p \wedge \sim p)$, my mathematical intuition that $2+2=4$, my epistemic intuition that every originary presentive intuition is a source of immediate justification, and arguably ethical intuitions and moral perceptions, all seem to have (more or less) justificatory force with regard to the respective judgments. But what is it that makes experiences justifiers; why do they have justificatory force?

Basically, what I want to achieve in this section is to show that Husserl subscribes to what I call a phenomenological conception of experiential justification (PCEJ). PCEJ holds that certain experiences gain their justificatory force from their distinctive phenomenology. ${ }^{18}$ More precisely, the claim is

PCEJ: Certain experiences have a distinctive, justification-conferring phenomenology, and if an experience $E$ has such a justification-conferring phenomenology with respect to proposition $p$, E provides immediate prima facie justification ${ }^{19}$ for believing that $p .^{20}$

\footnotetext{
${ }^{16}$ For Husserlian phenomenologists, who are used to Husserl's terminology and familiar with his arguments, it may seem absurd to hold that perception is judgment. Thus, it ought to be pointed out that Brentano and Meinong, for instance, have explicitly argued that perceptions essentially are judgments. Interestingly, based on his experimental investigations of the Müller-Lyer illusion, Vittorio Benussi, pupil of Meinong, argued that perception is distinct from judgment. Instead, he reasoned, perception, by its very nature, has the character of "presence" (Antonelli and Manotta 2009). I take this to show that while phenomenology is essentially an eidetic science, it still can benefit from empirical-experimental investigations. For an outstanding recent Husserl-inspired work that demonstrates how philosophicaldescriptive and scientific-empirical research can lead to the same results and thereby complement each other cf. Madary (2016).

17 I would like to point out that in the analytic tradition only very recently authors such as Michael Huemer have endorsed the view that perceptions could be propositional without being beliefs/judgments and thus without being in need of justification. Whether they are correct or whether perception has to be non-conceptual in order to be a source of immediate justification shall not be the topic of this paper.

18 By an experience's phenomenology I understand its phenomenal character, i.e., "what it is like subjectively to undergo the experience." (Tye 2015) As Siegel puts it, "It is definitional of experience, as the term is used here, that they have some phenomenal character, or more briefly, some phenomenology. The phenomenology of an experience is what it is like for the subject to have it." (Siegel 2016).

19 An experience E providing immediate prima facie justification for believing a proposition $p$ means (i) that having $\mathrm{E}$ is sufficient for justifiably believing that $p$ (the belief that $p$ is not in need of epistemic support of anything other than the underlying experience $\mathrm{E}$ - thus the justification is immediate, i.e., noninferential) and (ii) that the justification for believing that $p$ could be defeated, for instance by further experience - thus it is prima facie.

${ }^{20}$ I neither want to suggest that experiences are conceptual nor that Husserl thinks so. What I insist on, however, is that certain experiences immediately justify beliefs and that they do not just justify any belief but only those whose propositional contents are so to say in agreement with the experience's content. Some believe that this is only possible if experiences too have conceptual content, some deny this. I shall remain neutral on this issue.
} 
This means that Husserl's principle P6 introduced in the foregoing section is a specific version of PCEJ as P6 holds that certain experiences, namely intuitions, have justificatory force due to their distinctive, namely originally presentive, phenomenology. This section is supposed to shed further light on Husserl's version of PCEJ.

So far, the main reason I have presented for my claim that Husserl endorses PCEJ is the above-quoted passage in which Husserl says, "Immediate 'seeing' [...] as an originally presentive consciousness [...] is the ultimate legitimizing source of all rational assertions [...] because, and to the extent that, it is an originally presentive source." I call this the epistemological main thesis of Ideas I.

Is there more textual evidence for my claim? An important point of reference for any work on Husserl's epistemology should be Husserl's lectures on logic and epistemology from 1906/07 published in Hua XXIV and translated into English by Claire Ortiz Hill. There you can find a section devoted to the justificatory source of empirical statements (Hua XXIV, pp. 344-348). This section starts with the promise of giving "a closer examination of the phenomenological source of the justification of empirical judgments." (Hua XXIV, p. 344; 2008, p. 340) With respect to empirical judgments, Husserl raises the question, "Where does their justification come from? What substantiates them?" (Hua XXIV, p. 345; 2008, p. 341). His answer is: "Simple perception grounds a perceptual judgment. I see it, that's how it is. Why? I see it." (Hua XXIV, my translation) So perceptual judgments are justified by perceptions. What we are interested in, however, is how perceptions justify. Luckily, Husserl gives an answer to this question too.

A statement is grounded in experience, more precisely in perception and memory. It carries, so to speak, empirical weight. The clearer and more distinct the fulfilling empirical consciousness of givenness is, the more weight it carries. Obviously, we are not in a realm of contingent psychological subjectivity here either. Perception justifies by its phenomenological content, by its essence. Every singular perception with the same essence would justify "the same" statement proper to it in a precisely similar way, no matter where and for whom. (Hua XXIV, p. 347) ${ }^{21}$

Concerning the question of how perceptions justify, or, to put the question differently, of what it is that makes perceptions justifiers, this might be the single most important passage in Husserl's oeuvre. Let us call this passage the epistemological main passage of Husserliana 24 . Here we are told that "[p]erception justifies by its phenomenological content [my emphasis]" and that this phenomenological content also determines the degree of justification a perception exhibits.

Of course, "phenomenological content" is a technical term that is not easy to grasp and is not consistently used by Husserl. Broadly speaking, "[p]henomenological

\footnotetext{
21 This translation differs in one important respect from the translation offered by Hill (Husserl 2008, p. 343). Hill translates Husserl's claim that "[d]er Grund wiegt um so schwerer, je klarer und deutlicher das erfüllende empirische Gegebenheitsbewußtsein ist" as "[t]he more weight the grounds carry, the clearer and more distinct the fulfilling empirical consciousness of givenness is." I have reversed the order to highlight Husserl's message that the degree of clearness and distinctness of the empirical consciousness determines the experience's justificatory force (the clearer and more distinct, the more force it has).
} 
content is that which is contained in experience simply as lived." (Drummond 2007, p. 157) In his 1907 lecture on Thing and Space Husserl clarifies that the essence of perception is independent of the existence of the object perceived and that perception's essential character consists in giving its object in the flesh - even if the object does not exist, i.e., if the perceptual experience only is a hallucination.

Obviously, the foregoing characterization is not to be understood in the sense that there would pertain to the essence of every perception as such the existence of the perceived Object, the existence of that which stands there in it in the mode of presence in the flesh. In that case, talk of a perception whose object did not exist would indeed be countersensical; illusory perceptions would be unthinkable. It is the essential character of perception to be "consciousness" of the Object's presence in the flesh, i.e., to be the phenomenon of it. To perceive a house means to have the consciousness, to have the phenomenon, of a house standing there in the flesh. How matters stand with the so-called existence of the house, with the true Being of the house, and what this existence means - about all that nothing is said. (Hua XVI, p. 15; 1997, p. 12)

Put together, this passage and the epistemological main passage of Husserliana 24 entail that it is the phenomenological content, i.e., the essence of perception, that makes perception a source of justification and that this essence consists in being " "consciousness' of the Object's presence in the flesh" even if this object does not exist at all. This tells us two things. First, that Husserl subscribes to what we have called the phenomenological conception of experiential justification (PCEJ), according to which certain experiences are justifiers simply due to their phenomenology, i.e., their phenomenal character. Second - and this is only a minor point, but it helps to read Husserl correctly: Husserl uses the term "perception" not in the way current philosophers do. In current debates, perception is mostly introduced as a factive mental state. When you perceive that $p$, then $p$ is the case. More precisely, within the broad category of perceptual experience there is the distinction between (veridical) perception, illusion, and hallucination (cf., e.g., Soteriou 2016). Presupposing such a terminology, Husserl's talk of "illusory perceptions" and his claim that the object of perception might not exist, make no sense. Thus, it is important to keep in mind that what Husserl calls "perception" now goes under the label of "perceptual experience." 22

Thus, we have good reasons to interpret Husserl's saying that "[p]erception justifies by its phenomenological content, by its essence" as a commitment to PCEJ. The epistemological main passage of Husserliana 24, however, not only reveals Husserl's endorsement of PCEJ, but also indicates Husserl's specific version of PCEJ. Versions of PCEJ differ in what they take to be the distinctive, justificationconferring phenomenology that makes certain experiences justifiers. To put it differently, the question is what does this justification-conferring phenomenology look like? The epistemological main passage of Husserliana 24 suggests the

\footnotetext{
22 For Husserl's non-factive conception of perception cf. also Hua XXIV, p. 346 where Husserl emphasizes that perception can deceive.
} 
following answer: Perceptual experiences are justifiers because they have the phenomenal character of a "fulfilling empirical consciousness of givenness."

This fits well with Husserl's epistemological main thesis of Ideas I, according to which originary presentive intuitions are justifiers simply because they are "an originally presentive source." This conformity is further highlighted when Husserl says that "Originary, unbroken belief justifies simply because it is originary, namely as a quality of authentic consciousness of givenness and of that being fulfilled within its limits" (Hua XXIV, p. 346). This translation slightly differs from the translation offered by Hill, who translates "originär" with "primitive" (Husserl 2008 , p. 342). From the context it is clear that by originary belief Husserl means belief that is based on originary intuition. By "unbroken" belief Husserl means undefeated belief, which highlights that for Husserl justification provided by originary presentive intuition is prima facie justification. ${ }^{23}$ All this reinforces not only that Husserl subscribes to PCEJ but also that Husserl's specific version of PCEJ advocates that it is the originary presentive or self-giving character of certain experiences that makes them justifiers. Thus, we might say that the distinctive, justification-conferring phenomenology we are looking for is the phenomenology of originary givenness or self-givenness. ${ }^{24}$

Another important aspect of Husserl's version of PCEJ revealed by the epistemological main passage of Husserliana 24 is that empirical justification can come in degrees and that its degree corresponds to the level of clarity and distinctness of the empirical consciousness of givenness. ${ }^{25}$ This might seem to be of only minor importance, but in Section 4 we shall see the merits of this claim.

More eye-catching is Husserl's remark that with respect to his conception of perceptual justification, "[o]bviously, we are not in a realm of contingent psychological subjectivity here either. [...] Every singular perception with the same essence would justify 'the same' statement proper to it in a precisely similar way, no matter where and for whom." Whereas the second part of this statement signifies Husserl's internalist inclinations, the first part insists that his conception is non-subjective. This seems to be conflicting, as internalist conceptions of justification are typically associated with some kind of subjectivism while externalists emphasize the alleged objectivity of their systems.

With respect to internalist conceptions of justification, it is common to distinguish between two forms of internalism: access internalism and mentalism.

\footnotetext{
23 Prima facie justification is justification in the absence of defeaters. Strictly speaking, whenever I say that an experience provides justification or justifies a belief, what I want to say is that it provides prima facie justification or prima facie justifies a belief (cf. the formulation of PCEJ).

24 Husserl and I use the terms "originary givenness" and "self-givenness" interchangeably. Husserl describes the self-giving character of perception in the following way: "That perceptions are self-giving is quite familiar to you and should not give you any difficulties. Phenomenologically, 'self-giving' means here that every perception within itself is not only, in general, a consciousness of its object, but that it gives its object to consciousness in a distinctive manner. Perception is that mode of consciousness that sees and has its object itself in the flesh.” (Hua XI, p. 96; 2001, p. 140).

25 While our focus in this paper is on perceptual experiences, it is important to note that for Husserl even value-ceptions ("Wertnehmungen," e.g., moral perceptions) are originary presentive intuitions that "can be more or less clear or vague and distinct or confused." (Hua XXX 1996, p. 286; my translation).
} 
According to access internalism, there must be a special kind of access to what it is that makes a belief justified.

Access internalism: $\mathrm{S}$ is justified in believing $p$ only if $\mathrm{S}$ can become aware of what it is that makes her belief justified.

Mentalism, on the other hand, which has been introduced by Conee and Feldman as a novel kind of internalism, refers to the claim that justifying factors must be internal to a person's mental life (Conee and Feldman 2004, p. 55). More precisely, mentalism is often introduced as follows:

Mentalism: One's justification is determined entirely by one's (non-factive) mental states.

Mentalism entails that one's justification supervenes on one's mental states. Conee and Feldman specify their version of mentalism when they state:

C\&F: "[A]ll ultimate evidence is experiential evidence." (Conee and Feldman 2008, p. 86).

Accordingly, mentalists in the spirit of Conee and Feldman hold that one's ultimate justifiers are one's experiences. Access internalism and mentalism are different claims but they are not inconsistent. Externalists deny both access internalism as well as mentalism. Calling to mind that according to Husserl, "[i]mmediate 'seeing' [...] is the ultimate legitimizing source of all rational assertions," we have good reasons to view him as a mentalist internalist. ${ }^{26}$ Husserl's remark that perceptual experiences with the same phenomenology cannot differ in their justificatory force "no matter where and for whom" is also clearly mentalist as it indicates that an experience's justificatory force does not depend on factors like reliability but supervenes on the agent's mental life.

However, the main focus of this paper is not on Husserl's claim that one's ultimate justification is experiential justification, but on his claim that certain experiences are justifiers due to their distinctive, justification-conferring phenomenology. Because of this, and the fact that some commentators have recently challenged the claim that mentalism really is a commitment to internalism (cf. Butts 2012), I would like to make the following distinction:

Internalist conception of experiential justification: Experiences of type $\mathrm{T}$ are justifiers because of factors internal to experiences of that type.

Externalist conception of experiential justification: Experiences of type $\mathrm{T}$ are justifiers because of factors external to experiences of that type.

A factor $\mathrm{F}$ is internal to experiences of type $\mathrm{T}$ iff (i) $\mathrm{F}$ is a property of experiences of $\mathrm{T}$ and (ii) $\mathrm{F}$ is part of the mental life of the person who is having the experience. Reliability, for instance, is an external factor. If you hold that experiences of a certain type are justifiers because they are reliable, you are an externalist with respect to experiential justification of that type. An experience's phenomenology, on

\footnotetext{
${ }^{26}$ Whether or not Husserl's specific form of mentalism also commits him to access internalism is less clear and shall not be the topic of this paper.
} 
the other hand, is an internal factor. If you hold that experiences of a certain type are justifiers because of their distinctive phenomenology, you are an internalist with respect to experiential justification of that type. Thus, Husserl is an internalist with respect to perceptual justification. ${ }^{27}$

An experience's phenomenology, in contrast to its reliability, seems to be something subjective. It is not possible to share your experience's phenomenology in the same way as it is possible to share the information that $95 \%$ of your perceptual experiences have turned out to be veridical. In this sense, an experience's phenomenology is subjective, since it is private and cannot be shared.

Husserl, however, insists that his approach does not lead to a position that ascribes epistemic force to "contingent psychological subjectivity." How should we understand this claim? Is this even consistent with Husserl's experiential internalism? Here we need to take into account Husserl's repeated criticism of "the psychologistic prejudice" that "feelings of evidence" are the source of epistemic justification (Heffernan 1999, p. 84). Husserl stresses on several occasions that feelings of certainty can neither be a criterion for truth nor for justification (cf. Hua XXIV, pp. 153-156; 2008, pp. 151-154), and it is of crucial importance for him to point out that justification is not connected with the firmness of a conviction, but with the liveliness of an experience (cf. Hua XXIV, pp. 7-8; 2008, pp. 8-9).

This means that Husserl calling his version of internalism a non-subjective one is supposed to point out that only what is given within experience determines an experience's justificatory force and not how I feel about what is given to me. To put it differently, an experience's justification-conferring phenomenology includes its originally presentive or self-giving character but not the way I feel about what is presented to me.

As we shall see in the following sections, there currently are very prominent internalist approaches that hugely focus on mental states called seemings, and it is quite popular to hold that if it seems to one that $p$, then one has prima facie justification for believing that $p$. Such an approach, however, faces many problems, and we shall see that Husserl can avoid at least some of them because he subscribes to what I call a non-psychological ${ }^{28}$ internalist conception of experiential justification.

Non-psychological internalist conception of experiential justification:

Whether or not an (intuitional, perceptual, ...) experience has justificatory force and how much justificatory force it has depends on internal factors (e.g. its phenomenology), not including how strongly this experience pushes me towards believing a certain proposition.

\footnotetext{
27 As mentioned above, the focus in this paper is on perceptual justification, but I would like to emphasize again that according to Husserl experiential internalism is true for all types of justificationconferring experiences: If experiences of some type $\mathrm{T}$ are justifiers, they are because of factors internal to that type. They are, to be more precise, because of that type's distinctive phenomenology. For each different type, this justification-conferring phenomenology can be labeled phenomenology of originary givenness, but what this precisely means varies from type to type.

${ }^{28}$ I want to thank an anonymous referee of this journal for suggesting this terminology.
} 
This is contrasted with:

Psychological internalist conception of experiential justification:

Whether or not an (intuitional, perceptual, ...) experience has justificatory force and how much justificatory force it has depends on internal factors (e.g. its phenomenology), including how strongly this experience pushes me towards believing a certain proposition.

One last feature of Husserl's system of experiential justification I would like to point out is the incorporation of coherentist elements, as it is plausibly claimed that coherence of experience can contribute to a belief's overall justification. ${ }^{29}$ One such passage can be found directly following the epistemological main passage of Husserliana 24.

Moreover, if we proceed further in the context of perceptions and memories, then it becomes clear that the empirical weight increases with the comprehensiveness of the empirical context into which the individual experience concerned fits, i.e., fits without contradiction, therefore, becomes increasingly entwined with its neighbors in the sense of confirmatory agreement. (Hua XXIV, p. 347; 2008, p. 343)

This shows that for Husserl a single experience's justificatory force is increased if it is in "confirmatory agreement" with its fellow experiences. As pointed out by Christopher Erhard, Husserl's wording in this quote not only shows that he acknowledges the importance of coherence but also that he does so in a foundationalist way. Coherence increases justification, it does not produce justification (Erhard 2012, p. 57, fn 27).

Now let us summarize the features of Husserl's conception of experiential justification we have gathered in this section.

Husserl's conception of experiential justification:

H1: Certain experiences gain their justificatory force from their distinctive phenomenology/phenomenal character.

$\mathrm{H} 2$ : Experiential justification is prima facie justification, viz. justification that can be defeated, for instance by further experience. ${ }^{30}$

\footnotetext{
29 In footnotes 11 and 12 , we have pointed out that foundationalists can acknowledge that coherence plays an important epistemic role. They only have to deny that coherence is necessary or sufficient for justification. They do not have to deny that coherence can provide additional justification or that a lack of coherence can reduce the degree of justification.

${ }^{30}$ Of course, Husserl's foundationalism has it that ultimately any experience can only be defeated by another experience. "Cancellation [Durchstreichung] of something experienced can also be due to 'secure knowledge,' due to non-intuitive [unanschaulich] certainties, but such a cancellation can only be justified by appeal to [Rekurs auf] fulfilling processes of actually present rival experiences." (Hua XX/1 2002, p. 196) Consider the Müller-Lyer illusion. In this case, your experience provides you with prima facie justification for believing that the lines differ in length. This justification is defeated by your knowledge that the lines are equal in length. This knowledge, however, must ultimately be based on foregoing experiences that reveal the illusory nature of this figure.
} 
H3: Experiential justification can be increased by coherence with other experiences/beliefs.

H4: Two perceptual experiences with the same overall phenomenology (or "essence") cannot differ in what and how they justify.

H5: The distinctive, justification-conferring phenomenology that makes (perceptual) experiences justifiers might be called phenomenology of originary givenness or phenomenology of self-givenness.

H6: An experience's phenomenology of self-givenness is determined by what is originally given within experience and not by how the subject feels about what is given.

H7: The same is true for experiential justification. (An experience's justificatory force is determined by what is originally given within experience and not by how the subject feels about what is given.)

H8: More precisely, a perceptual experience's justificatory force is determined by how clear and distinct it presents its objects/contents.

H1 simply is the defining thesis of PCEJ. Every proponent of PCEJ must subscribe to it. $\mathrm{H} 2$ and $\mathrm{H} 3$ are highly plausible. Every non-skeptic about the possibility of experiential justification should subscribe to them. $\mathrm{H} 4$ is a claim about epistemic justification typical for internalists. In current debates, H4 is very popular, especially due to the so-called new evil demon problem (cf. Silins 2014).

H5-H8 are the defining features of Husserl's specific version of PCEJ. The terms "originary givenness" and "self-givenness" provided by H5 to denote the distinctive, justification-conferring phenomenology of certain experiences indicate what is fleshed out in H6 and H7: experiential justification is non-psychological in the sense that it is a matter of what is given and how it is given and not of how one feels about what is given. As we have seen, this means that Husserl endorses what I call a non-psychological internalist conception of experiential justification. This non-psychological internalist conception is in stark contrast to currently popular versions of internalism such as Huemer's Phenomenal Conservatism and Ole Koksvik's version of PCEJ. In Section 4, I will show the merits of this nonpsychological internalist conception by contrasting it with Huemer's and Koksvik's conceptions. In short, the non-psychological internalist conception can rule out counter-examples that pose a threat to internalism in general and PCEJ in particular. $\mathrm{H} 8$, finally, specifies that at least in the case of perceptual experiences, the extent to which the experience's object is given clearly and distinctly determines the experience's justificatory force. We shall see not only that this is the natural view of perceptual justification but also how this view is superior to the conceptions of Huemer and Koksvik.

\section{Different Versions of PCEJ in Current Debates}

In analytical debates of the twenty-first century, the roots of PCEJ can be found in Michael Huemer's principle of phenomenal conservatism (PC), first formulated in Huemer (2001). According to Huemer's PC, prima facie justification for beliefs 
about the external world, the inner world, mathematics, ethics and so forth, is easily accessible:

PC: "If it seems to $S$ as if $P$, then $S$ thereby has at least prima facie justification for believing that $P$." (Huemer 2001, p. 99)

Huemer's PC has become very popular, and even opponents of PC tend to agree that seemings are mental states that should be a focus of epistemological investigations. But what is a seeming and what features does it exhibit? The attempt to analyze the notion of "seeming" turns out to be extremely difficult. Typically, proponents of PC do not try to give a proper analysis but use examples to clarify this notion. The most common types of seemings are perceptual, introspective, memory based, and intellectual seemings. When I see my black laptop in front of me, it visually seems to me that there is a black laptop. This is an example of a perceptual seeming. When I realize that $2+2=4$, it intellectually seems to me that $2+2=4$. According to proponents of PC, rational intuitions are intellectual seemings. Furthermore, they typically claim that there are crucial similarities between intellectual cognition and sensory perception, in that seemings like $2+2=4$ should be regarded as a form or a product of intellectual seeing.

There is some agreement among phenomenal conservatives that seemings are sui generis propositional entities. Sui generis means that seemings are irreducible. They especially cannot be reduced to beliefs or inclinations to believe. Chris Tucker calls this the experience-view: "A seeming that $\mathrm{P}$ is: [...] An experience with the content P or a sui generis propositional attitude that P." (Tucker 2013, p. 3) The most distinctive feature of seemings, however, is that they present their contents as true. "The real difference between seemings and other states that can incline one to believe their contents is that seemings have the feel of truth, the feel of a state whose content reveals how things really are." (Tolhurst 1998, pp. 298-299) In this context Huemer speaks of the "forcefulness" of seemings, whereas Tucker prefers the term "assertiveness."

As I interpret Huemer, seemings have a distinctive phenomenology. This means that Huemer's PC agrees with PCEJ that certain justification-conferring experiences are unified by their distinctive phenomenology. The reason I do not interpret Huemer as a proponent of PCEJ is that he never explicitly states that seemings are justifiers due to their phenomenology. For him, being a seeming is sufficient for having justificatory force, but he does not hold that a seeming has justificatory force qua having this distinctive seeming-phenomenology. We have to distinguish the following questions:

Q1: What makes certain experiences justifiers, i.e., why do they possess justificatory force?

Q2: Why should we hold the view that certain experiences are justifiers? 
Huemer is primarily concerned with Q2 and his main argument is his self-defeat argument, according to which arguing against $\mathrm{PC}$ is necessarily self-defeating (cf. Huemer 2007). ${ }^{31} \mathrm{We}$, however, are interested in Q1.

There are a number of possible answers to Q1. It is illuminating to take a closer look at James Pryor's perceptual dogmatism. By "dogmatism" Pryor understands the claim that immediate (yet underminable) justification is possible (cf. Pryor 2013). Pryor is a perceptual dogmatist; he holds that immediate (yet underminable) perceptual justification is possible. In specifying his version of perceptual dogmatism, Pryor elucidates:

My view is that our perceptual experiences have the epistemic powers the dogmatist says they have because of what the phenomenology of perception is like. I think there's a distinctive phenomenology: the feeling of seeming to ascertain that a given proposition is true. This is present when the way a mental episode represents its content makes it feel as though, by enjoying that episode, you can thereby just tell that that content obtains. (Pryor 2004, p. 356f.)

This means that Pryor ascribes the justificatory force of perceptual experiences to their distinctive phenomenology. Thus, Pryor is a proponent of PCEJ. He claims that certain experiences - namely, perceptual experiences - are justifiers due to their distinctive phenomenology. The following authors all agree that certain experiences gain their justificatory force from their distinctive phenomenology, but they differ in their respective characterizations of this distinctive phenomenology.

Church: Certain experiences are self-justifying due to their phenomenology of objectivity (cf. Church 2013, chapter 1 and Section 4 in chapter 4).

Koksvik: Perceptual and intuitional experiences singlehandedly justify belief due to their phenomenology of objectivity ${ }^{32}$ and phenomenology of pushiness (cf. Koksvik 2011, p. 209).

Bengson: "[C]ertain mental states provide prima facie justification for corresponding beliefs" due to their "presentationality", i.e., their presentational character (Bengson 2015, p. 741). ${ }^{33}$

Chudnoff: "If your perceptual [or intuitional] experience representing that $p$ justifies you in believing that $p$ it does so because it has a certain

\footnotetext{
31 This argument is highly controversial and even proponents of PC have dismissed it (cf. Tucker 2013, p. 9, fn 22 and Lycan 2013, p. 299, fn 8). Tucker (2010) holds that PC should be endorsed not because of Huemer's self-defeat argument, but due to its explanatory power, as several philosophical problems can be solved by subscribing to PC. But even if so, we still do not know why certain experiences are justifiers.

32 It should be noted that Church and Koksvik have developed their respective concepts of "phenomenology of objectivity" independently from each other and that they differ in important details.

33 In Bengson 2015 it is rather clear that "presentationality" is meant to be an experience's characteristic phenomenology, and with respect to Bengson's earlier works, Koksvik elucidates, "That the 'presentationality' of perception and intuition is intended as (at least partly) a phenomenal feature is perhaps not one hundred percent clear from the texts, but Bengson has confirmed this interpretation of his view in conversation." (Koksvik 2011, p. 187, fn 212).
} 
phenomenal character," namely a "presentational phenomenology with respect to p." (Chudnoff 2013, p. 37)

Husserl: Certain experiences are justifiers due to their phenomenology of selfgivenness.

All these positions are versions of PCEJ, since they claim that certain experiences are justifiers simply due to their distinctive phenomenology. ${ }^{34}$ They are all different versions of PCEJ, since they define this distinctive phenomenology differently. Pryor differs from the other ones, since he restricts PCEJ to perceptual experiences.

This section was supposed to show that there is a movement in current analytic epistemology that shares with Husserl the basic commitment to PCEJ. This, however, is only the first step in revealing the currency and relevance of Husserl's approach to experiential justification. The second and arguably more important one is to show that Husserl's version of PCEJ has some advantages and that current analytic epistemology could benefit from adopting elements of Husserl's epistemology. To that end, I want to focus on problems that arise for Koksvik's version of PCEJ and show how Husserl is in a perfect position to deal with these problems. The reason I want to focus on Koksvik, and not, for instance, on Chudnoff, is that Koksvik, as well as Huemer's very influential PC, suffer from the same shortcoming, so that contrasting Husserl's with Koksvik's version allows me to most efficiently point out the benefits of Husserl's version.

There are at least two further steps in revealing the full force and relevance of Husserl's version of PCEJ. The third would be to demonstrate that Husserl's version has some advantages not only over Koksvik's but also over the other current versions of PCEJ - for instance by showing that the other ones are less successful in avoiding or explicating the problems of Koksvik's version. The fourth one would be to argue for PCEJ as such, i.e., to show that and how PCEJ is superior to rival conceptions of experiential justification such as reliabilism.

Taking the third and the fourth step, of course, would go beyond the scope of the present paper. Thus, in what follows, I shall attempt to take the second step by presenting the problems that arise for Koksvik and Huemer and showing how Husserl's approach offers the ideal framework to deal with these problems.

\section{Husserl's Advantages}

Koksvik vs. Pryor: One characteristic feature of justification, be it experiential or non-experiential, perceptual or rational, is that it comes in degrees. Thus, any version of PCEJ has to explain how different experiences can provide different degrees of justification. For PCEJ is the claim that certain experiences gain their justificatory force from their distinctive phenomenology, which means that this justification-conferring phenomenology needs to be constituted such that it can also come in degrees. Different experiences can differ in the degree of justification they provide because they can differ in their respective phenomenology. Experiences do

\footnotetext{
34 It ought to be pointed out that Chudnoff (2013) and Church (2013) explicitly refer to Husserl.
} 
not merely either have or not have a justification-conferring phenomenology; they can have it in a more or less pronounced way. The more pronounced, the more justification they provide.

To highlight how an experience's justificatory force depends on the quality of its phenomenology, Koksvik gives the following example.

Blizzard: Ann is standing stationary on a flat, snow-covered plain in a blizzard. The wind is whipping snow around in all directions, and no features of the landscape are visible. Ann can barely see her own knees, and she cannot see the tips of her skis. Someone approaches very slowly from the direction in which Ann is looking. At first she is completely unable to distinguish the approaching person from patterns randomly forming and dissipating in the snow. As the person approaches, Ann's perceptual experience changes, the human figure gradually appears more and more clearly. (Koksvik 2011, pp. 187, 223)

It is beyond doubt that Ann's justification increases as this person in front of her approaches and "appears more and more clearly." Any plausible conception of experiential justification must be able to account for examples like this. Koksvik argues that Pryor's phenomenological conception of perceptual conception does not. Remember, Pryor claims that the distinctive justification-conferring phenomenology of perceptual experiences consists in "the feeling of seeming to ascertain that a given proposition is true" so that by having this experience you can "just tell that that content obtains." Koksvik calls this "the phenomenology of seeming able to just tell'" (Koksvik 2011, p. 222), and objects that in Blizzard Ann has some justification that a person is approaching "well before Ann's experience takes on the character of seeming able to just tell that there is." (Koksvik 2011, p. 223) More generally, he observes that Pryor's version of PCEJ is "ill-suited" to account for the fact that "justification is a matter of degree." (Koksvik 2011, p. 227)

This criticism seems justified, as it is hard to see how this phenomenal character of seeming able to just tell that something is true can increase or decrease and hence appropriately depict experiential justification.

How about Husserl? Does his conception of PCEJ offer an explanation of how justification can come in degrees? As we have seen, it does. In the epistemological main passage of Husserliana 24 Husserl not only tells us that empirical justification comes in degrees but also that it is the clearness and distinctness of an experience's phenomenology of self-givenness that determines the experience's degree of justification. The clearer and more distinct, the more justification is provided. In what follows, we shall illustrate this, and while I agree with Koksvik that Pryor's concept cannot explain the occurrence of different degrees of perceptual justification, we will point out the shortcomings of Koksvik's own explanation and reveal how Husserl can avoid them.

Husserl vs. Huemer and Koksvik: As we have seen, Koksvik explains the justification-conferring character of perceptual and intuitional experiences by their phenomenology of objectivity and phenomenology of pushiness. He explains: "An experience has phenomenology of objectivity when its purporting to be about the way things are, objectively speaking, is itself an aspect of its character. It has 
phenomenology of pushiness when its pushing its subject to accept its content is itself an aspect of its character." (Koksvik 2011, p. 260) The fact that perceptual justification comes in degrees is explained by the fact that the "[p]henomenology of pushiness comes in degrees." (Koksvik 2011, p. 243) Hence, our focus will be on this second aspect, the phenomenology of pushiness.

What does Koksvik mean by saying that this feature of pushing its subject to believe something "is itself an aspect of" such an experience's character? The conception of pushiness may be formulated as follows:

Phenomenology of pushiness: When you have an experience with content $\mathrm{C}$ and by having this experience you are pushed to accept $\mathrm{C}$, this experience has phenomenology of pushiness.

This is also what proponents of phenomenal conservatism such as Michael Huemer and Chris Tucker have in mind when they talk about seemings. ${ }^{35}$ In the following, I will use phrases like "it seems to one that $p$ " and "one is pushed towards believing $p$ " synonymously. Just as Koksvik holds that degrees of experiential justification can be explained by degrees of pushiness, Huemer does the same with respect to a seeming's strength:

Some appearances are stronger [my emphasis] than others - as we say, some things are "more obvious" than others - and this determines what we hold on to and what we reject in case of conflict. [...] Things can become complicated when many different beliefs and/or appearances are involved, but the basic principle is that we are more inclined to accept what more strongly seems [my emphasis] to us to be true. (Huemer 2005, p. 100) (36 $^{36}$

Obviously, Koksvik and Huemer's claim that the phenomenology of pushiness comes in degrees is true. By having an experience, you can be pushed more or less towards believing its content. But does this properly explain degrees of justification? Is an experience's justificatory force really determined by its degree of pushiness?

Let us again consider Koksvik's Blizzard example. The closer the person in front of Ann gets, the more clearly this person appears to Ann, the more she is pushed towards believing that there is a person in front of her, and the more she is justified in believing so. This seems to be a totally plausible story of how perceptual justification works. However, we have to keep in mind that according to Koksvik and Huemer an experience's justificatory force is entirely determined by its phenomenology of pushiness. As the person in front of Ann approaches, Ann's justification does not increase because the person "appears more and more clearly," but solely because Ann is more and more pushed towards believing that there is a person approaching. Note that this reveals an important difference from Husserl's conception. For Husserl, it simply does not matter how strongly a perceptual

\footnotetext{
35 Tucker offers the following definition of a seeming's phenomenology: "The phenomenology of a seeming makes it feel as though the seeming is 'recommending' its propositional content as true or 'assuring' us of the content's truth. The phenomenological character of assertiveness comes in degrees." (Tucker 2010, p. 530).

36 It should be mentioned that Huemer uses the terms "seemings" and "appearances" synonymously.
} 
experience pushes one towards believing something. All that matters is how clearly and distinctly the object or state of affairs is presented within experience.

In my opinion, the main problem for Koksvik and Huemer is that there is no necessary link between how a specific object/content is given to me within experience and how strongly I am pushed towards believing this content. Different people can have appearances of the same clarity and distinctness and yet differ significantly in how they are pushed by these appearances. ${ }^{37}$ However, being extremely pushed by an experience that lacks clarity and distinctness seems irrational and unjustified.

Peter Markie has raised two influential counter-examples against Huemer's PC (cf. Markie 2005). ${ }^{38}$ In both of these counter-examples, a seeming occurs that intuitively should not be regarded as a source of justification. Or so Markie's argument goes. The seeming in the first example is the product of wishful thinking, the seeming in the second counter-example is caused by a cognitive malfunction. Let us have a closer look at the second example.

Cognitive Malfunction: "Suppose that I perceive the walnut tree in my yard, and, having learned to identify walnut trees visually, it seems to me that it is a walnut tree. The same phenomenological experience that makes it seem to me that the tree is a walnut also makes it seem to me that it was planted on April 24,1914 . Nothing in the phenomenological experience or my identification skills supports things seeming this way to me. There is no date-of-planting sign on the tree, for example. Cognitive malfunction is the cause of its seeming to me in perception that the tree was planted on that date." (Markie 2005, p. 357)

In this example, a visual experience is accompanied by two seemings with very different contents.

$\mathrm{S} 1^{39}$ : "This tree is a walnut."

S2: "This tree was planted on April 24, 1914."

Intuitively, one is only justified in believing $\mathrm{S} 1$ but not $\mathrm{S} 2$. However, if $\mathrm{S} 2$ is a seeming but no justifier, then Huemer's PC is refuted. Contrasting Husserl's conception of self-givenness with Koksvik's conception of phenomenology of pushiness, we can say that this experience has phenomenology of pushiness with respect to $S 1$ and $S 2$ but phenomenology of self-givenness only with respect to $S 1$. This experience does not have phenomenology of self-givenness with respect to S2 because no specific date of planting is originally given within experience. The

\footnotetext{
37 To be sure, even the very same person can have (and often has) appearances of the same clarity and distinctness and yet be pushed very differently by these appearances (for instance, if there is wishful thinking involved).

38 For another critical analysis of Huemer's PC cf. Hopp (2016). For a more sympathetic phenomenological analysis cf. Rinofner-Kreidl (2013, pp. 46-48) who highlights that the "fidelity to appearances" is a fundamental epistemological conviction shared by Huemer and (Husserlian) phenomenologists.

39 In the following, "S1" (or "S2") refers either to the mental state - seeming 1 - that has a specific content or to the content itself.
} 
content S2 is, so to speak, only a representational but not a presentational content of your experience. The mental state S2 is what I call an empty seeming, i.e., a mental state that has phenomenology of pushiness but lacks phenomenology of selfgivenness. Its content is not experienced as bodily present, is not given in a fleshed out manner. Note also that a content such as S2 cannot be given in varying degrees of clarity and distinctness.

Since Huemer and Koksvik, unfortunately, do not respond to Markie's Cognitive Malfunction, one might object that it is unclear whether they would view such empty seemings as seemings at all. Luckily, however, there is another, more downto-earth example that is discussed by Huemer and other phenomenal conservatives such as Tucker. This is the phenomenon of blindsight. Tucker describes this phenomenon as follows:

Subjects who have a damaged visual cortex often emphatically report that they cannot see anything within a certain region of their visual field. Nonetheless, such subjects often show remarkable sensitivity (though less than properly functioning humans) to such things as motion, the orientation of objects, and the wavelength of light within their reported "blind spot". These subjects are typically surprised to discover their success, thinking that they were making random guesses. (Tucker 2010, p. 530)

The point is that phenomenal conservatives such as Tucker and Huemer hold that blindsighted people have seemings about what is going on in their blind spots and that these seemings provide some prima facie justification (Tucker 2010, p. 530f.; Huemer 2013, p. 333). They claim that these seemings only have little justificatory force because they are weak (i.e., their phenomenology of pushiness is not very pronounced). There are three things to note. First, a plausible version of experiential justification should deny that such blindsight seemings can provide any immediate justification (about what is going on in one's blind spots). Blindsight examples are very similar to BonJour's famous case of Norman the clairvoyant, and it seems obvious that internalists who deny that Norman has immediate justification for believing his prophecies must also deny that blindsight seemings are a source of immediate justification (cf. Ghijsen 2016, pp. 17-19 and Smithies 2014, p. 103f.). Second, even if a person's blindsight seemings were very strong in the sense of pushing one very strongly towards believing their contents, these seemings would still be incapable of providing immediate justification. Thirdly, our Husserlian conception of PCEJ can straightforwardly explain why such blindsight seemings do not have justificatory force. These seemings are empty seemings. By definition, they lack typical perceptual phenomenology. It merely seems to you that something is going on in these blind spots, but this content is not given to you in its presence, in varying degrees of clarity and distinctness.

From the foregoing, it should be clear not only that Husserl can avoid such problems but also that he is in a perfect position to do so. By discussing the example of Cognitive Malfunction and the phenomenon of blindsight, we have seen that an experience's justificatory force cannot be determined by how strongly an experience pushes one to believe something. Instead, they suggest that an experience's justificatory force has to be linked to what is given within experience, how it is 
given (emptily vs. originally), and, at least in the case of perceptual experiences, how clearly and distinctly it is given. This, however, is precisely what is suggested in Husserl's epistemological main passage of Husserliana 24 and what we have illustrated in detail at the end of Section 2 (cf. especially the features H6-H8).

We might frame the main difference between Huemer and Husserl as follows: Huemer holds that every seeming, even empty seemings, ${ }^{40}$ are a source of justification. $^{41}$ Husserl, on the other hand, gives a detailed and demanding phenomenological analysis of what phenomenal character an experience must have in order to have justificatory force. As we have seen, it is precisely this demand of having a phenomenology of self-givenness that allows for avoiding the type of counter-examples we have raised against Huemer and Koksvik. Thus, Koksvik, Huemer, and Husserl all allow for the possibility of degrees of experiential justification, but only Husserl does so in a satisfactory manner.

Finally, I would like to mention a distinctively phenomenological/Husserlian objection to Huemer's conception. For Huemer, the distinctive, justificationconferring phenomenal character of every type of justification-providing mental state is precisely the same one. Whether something is a sensory perception or an act of introspection, a memory or a mathematical intuition, a moral perception or an intuition of a general moral principle, in all these cases the respective act has its justificatory force simply by virtue of its seeming-character. Such an account is phenomenologically superficial at best.

What is also missing in Huemer's conception is a Husserlian-style phenomenological analysis of what it means for an object of a specific type to be given within a justification-conferring experience. Say, it seems to one person that " 2 is the only even prime number" because her teacher told her so and to another because of her understanding of the terms involved. Do they have the same seeming? Do they have the same kind and degree of justification? Say, it seems to one person that "The main church in City $\mathrm{C}$ is on fire" simply because she hopes that this is true and to another because she is visually aware of it. One might respond that we have to distinguish between perceptual, intellectual, and so to say "empty" seemings, but this is precisely the point. Huemer and other phenomenal conservatives do not offer a phenomenological analysis of what a seeming is and how its justificationconferring phenomenal character depends on the respective type of the object of the seeming. Consequently, it is difficult for them to differentiate between empty

\footnotetext{
${ }^{40}$ Perhaps one should not criticize Huemer for holding that even empty seemings carry justificatory force but rather for being unable to exclude such cases. Being able to exclude such cases, however, is only possible by providing a more detailed phenomenological analysis of what justification-conferring mental states look like.

41 Referring to the distinction between psychological and non-psychological internalist conceptions of justification we made in Sect. 2, this means that Huemer, in contrast to Husserl, champions psychological internalism.
} 
seemings and justification-conferring ones, which is precisely why Husserl's criticism that justification-conferring experiences must not be confused with feelings of evidence can be considered an objection to PC. ${ }^{42}$

For Husserl, it is clear that "evidence is a function of the evident." (Heffernan 1998, p. 26) This means that the type of object I experience determines the type of evidence that is available to me (e.g., inadequate evidence for physical objects, apodictic evidence for mathematical truths, and adequate evidence for my existence). Husserl is interested in what it means to experience, for instance, a physical object, how such an object can be given within experience, and what it means that in perception such an object is self-given, i.e., originally given. The answers to these questions are essential insights and independent of a subject's psychology, culture, or history.

To put it differently: Every originary presentive intuition provides immediate prima facie justification, but what originary givenness means depends on the type of object that is given. Originary givenness of ordinary objects such as tables and chairs, for instance, differs from the originary givenness of mathematical truths in that, with respect to the former, only inadequate evidence is possible, which means that they can only be given inadequately, i.e., in adumbrations. The appropriate type of evidence for the latter is apodictic evidence. When you have apodictic evidence of $p$, you "see" why $p$ is necessarily true.

The importance of this insight on Husserl's philosophical work can hardly be overestimated:

The first breakthrough of this universal a priori of correlation between experienced object and manners of givenness (which occurred during work on my Logical Investigations around 1898) affected me so deeply that my whole subsequent life-work has been dominated by the task of systematically elaborating on this a priori of correlation. (Hua VI, p. 169; 1970, p. 166, note)

Husserl makes clear that

Only a systematic analysis, namely an eidetic analysis of consciousness with respect to all its basic types, with respect to all its eidetic correlations can solve the problems of a critique of reason, can lead to a unanimous and completely sufficient noetics. That it belongs to the essence of all consciousness to be consciousness of something is the starting point. But for every basic type of objectivity, consciousness, and more precisely presentive consciousness, is characterized differently, it has different eidetic structures that a priori

\footnotetext{
$\overline{42}$ Brogaard, for instance, states with respect to rational seemings: "Personally, I would probably describe the attraction to certain propositions that accompanies intuitions as a feeling (which does have a phenomenology) rather than as a phenomenology. The feeling is an urge (or inclination) to believe merely based on understanding that is so intense that we have a hard time envisaging that others may not feel the same way." (Brogaard 2014, p. 388f., my emphasis) On our view, in contrast, an experience is not a justifier because it psychologically urges us to believe some proposition but only if it exhibits a justification-conferring phenomenology such that the presence of the experience's object is given within experience.
} 
correlate to the essence of the respective objectivity. ${ }^{43}$ (Hua XXX 1996, p. 329f.; my translation)

This is why a Husserlian transcendental phenomenology has an intrinsic epistemological $^{44}$ component: via his conception of the correlational a priori, Husserl closely connects transcendental phenomenology with a theory of evidence. Different types of objects are linked to different types of evidence, and different types of evidence are in turn distinguished phenomenologically, namely in terms of different types of originary givenness. With respect to physical objects, originary givenness means that the object is given "in the flesh" in varying degrees of clarity and distinctness. Such evidence is inadequate in that physical objects can only be given in adumbrations. There is a crucial phenomenological difference in the givenness of logical or mathematical truths. Here we can have apodictic evidence; they are not simply given "in the flesh," they are given as indubitable. We may say that in the case of physical objects or states of affairs, I can see that something is the case, e.g., that there is a table in front of me. By having apodictic evidence, on the other hand, I can see that something has to be the case and could not be different, which means I can see why something has to be the case, e.g., that 2 is the only even prime number.

Thus, even if Huemer is on the right track, what is required is a much more detailed phenomenological analysis of justification-conferring experiences. ${ }^{45}$

Husserl and Huemer agree that there is a certain type of experience that has to be viewed as a source of immediate justification. While Husserl ascribes justificatory force to all originary presentive intuitions, Huemer does so for all seemings. In current debates, Huemer's approach enjoys widespread popularity, and while I believe that Huemer is on the right track in his basic proposal of respecting appearances, I hope to have shown that Husserl's conception exhibits significant advantages and that current debates in epistemology could significantly benefit from adopting Husserl's version of PCEJ.

Acknowledgements Open access funding provided by University of Graz. Philipp Berghofer is a recipient of a DOC Fellowship of the Austrian Academy of Sciences at the Department for Philosophy at the University of Graz. I wish to thank Sonja Rinofner-Kreidl, George Heffernan, Elijah Chudnoff, and Walter Hopp for many enlightening discussions. Also, many thanks to Harald Wiltsche, Michi Wallner, Marian David, and an anonymous referee for many important clarifications.

\footnotetext{
43 "Nur eine systematische Analyse, und zwar eine Wesensanalyse des Bewußtseins nach allen seinen Grundartungen, nach allen seinen Wesenskorrelaten kann die Probleme der Vernunftkritik lösen, kann eine einstimmige und voll ausreichende Noetik leisten. Daß es zum Wesen $<$ von $>$ jederlei Bewußtsein gehört, Bewußtsein von etwas zu sein, das ist der Ausgangspunkt. Aber für jede Grundart von Gegenständlichkeit ist das Bewußtsein und näher das gebende Bewußtsein anders charakterisiert, es hat andere Wesensgestaltungen, die mit dem Wesen der betreffenden Gegenständlichkeiten a priori zusammenhängen".

${ }^{44}$ Cf. Luft (2004, p. 204).

45 Cf. also Audi's remark: "The question raised by these and other points (and so far only implicit in our discussion) is whether seemings are a basic ground of rationality (or justification) or rather an important sufficient condition for it. Even unrestricted phenomenal conservatism is not usually formulated in a way that entails the former. The question is difficult to answer in the absence of a very detailed phenomenolgical account of seemings (something I hope is forthcoming) [...]" (Audi 2013, p. 194) On the need for a phenomenological analysis in the context of PC, see also Wiltsche (2015).
} 
Open Access This article is distributed under the terms of the Creative Commons Attribution 4.0 International License (http://creativecommons.org/licenses/by/4.0/), which permits unrestricted use, distribution, and reproduction in any medium, provided you give appropriate credit to the original author(s) and the source, provide a link to the Creative Commons license, and indicate if changes were made.

\section{References}

Antonelli, M., \& Manotta, M. (2009). Meinongs und Benussis Phänomenologie der Wahrnehmung. Meinong Studies, 3, 123-173.

Audi, R. (2013). Doxastic innocence: Phenomenal conservatism and grounds of justification. In C. Tucker (Ed.), Seemings and justification. New essays on dogmatism and phenomenal conservatism (pp. 181-201). Oxford: Oxford University Press.

Bengson, J. (2015). The intellectual given. Mind, 124(495), 707-760.

Berghofer, P. (2017). Why Husserl is a moderate foundationalist. Husserl Studies. https://doi.org/10. 1007/s10743-017-9213-4.

BonJour, L. (1985). The Structure of Empirical Knowledge. Cambridge: Harvard University Press.

Brogaard, B. (2014). Intuitions as intellectual seemings. Analytic Philosophy, 55(4), 382-393.

Butts, E. (2012). Mentalism is not epistemic ur-internalism. Philosophical Explorations, 15(2), 233-249.

Chudnoff, E. (2013). Intuition. Oxford: Oxford University Press.

Church, J. (2013). Possibilities of perception. Oxford: Oxford University Press.

Conee, E., \& Feldman, R. (2004). Evidentialism: Essays in epistemology. Oxford: Oxford University Press.

Conee, E., \& Feldman, R. (2008). Evidence. In Q. Smith (Ed.), Epistemology: New essays (pp. 83-104). Oxford: Oxford University Press.

Drummond, J. (2007). Historical dictionary of Husserl's philosophy. Lanham, MD: The Scarecrow Press.

Erhard, C. (2012). Husserls moderater empirischer Fundamentalismus und das Verhältnis zwischen Phänomenologie, Ontologie und Metaphysik. Kommentar zu Christian Beyer. In J. Nida-Rümelin \& E. Özmen (Eds.), Welt der Gründe (pp. 31-47). Hamburg: Meiner.

Ghijsen, H. (2016). The puzzle of perceptual justification. Dordrecht: Springer.

Heffernan, G. (1998). Miscellaneous lucubrations on Husserls's answer to the question 'was die Evidenz sei': A contribution to the phenomenology of evidence on the occasion of the publication of Husserliana Volume XXX. Husserl Studies, 15, 1-75.

Heffernan, G. (1999). A study in the sedimented origins of evidence: Husserl and his contemporaries engaged in a collective essay in the phenomenology and psychology of epistemic justification. Husserl Studies, 16, 83-181.

Hopp, W. (2016). Phenomenal conservatism and the principle of all principles. In D. Dahlstrom, A. Elpidorou, \& W. Hopp (Eds.), Philosophy of mind and phenomenology (pp. 180-202). New York: Routledge.

Hua III/1. Husserl, E. (1976). Ideen zu einer reinen Phänomenologie und phänomenologischen Philosophie. Erstes Buch. K. Schuhmann (Ed.). The Hague: Nijhoff; Ideas pertaining to a pure phenomenology and to a phenomenological philosophy. First Book. F. Kersten (Trans.). The Hague: Nijhoff, 1982.

Hua VI. Husserl, E. (1976). Die Krisis der europäischen Wissenschaften und die transzendentale Phänomenologie. Eine Einleitung in die phänomenologische Philosophie. W. Biemel (Ed.). The Hague: Nijhoff; The crisis of European sciences and transcendental phenomenology. An introduction to phenomenological philosophy. D. Carr (Trans.). Evanston: Northwestern University Press, 1970.

Hua XI. Husserl, E. (1966). Analysen zur passiven Synthesis. M. Fleischer (Ed.). The Hague: Nijhoff; Analyses concerning passive and active synthesis. A. J. Steinbock (Trans.). Dordrecht: Kluwer, 2001.

Hua XVI. Husserl, E. (1973). Ding und Raum: Vorlesungen 1907. U. Claesges (Ed.). The Hague: Nijhoff; Thing and space: Lectures of 1907. R. Rojcewicz (Trans.). Dordrecht: Kluwer, 1997.

Hua XVII. Husserl, E. (1974). Formale und transzendentale Logik. P. Janssen (Ed.). The Hague: Nijhoff. 
Hua XIX/1-2. Husserl, E. (1984). Logische Untersuchungen. Zweiter Band. Untersuchungen zur Phänomenologie und Theorie der Erkenntnis. U. Panzer (Ed.). The Hague: Nijhoff.

Hua XX/1. Husserl, E. (2002): Logische Untersuchungen. Ergänzungsband. Erster Teil. Entwürfe zur Umarbeitung der VI. Untersuchung und zur Vorrede für die Neuauflage der Logischen Untersuchungen (Sommer 1913). U. Melle (Ed.). Dordrecht: Kluwer.

Hua XXIV. Husserl, E. (1984). Einleitung in die Logik und Erkenntnistheorie. Vorlesungen 1906/07. U. Melle (Ed.). Dordrecht: Nijhoff; Introduction to logic and theory of knowledge. Lectures 1906/07. C. O. Hill (Trans.). Dordrecht: Springer, 2008.

Hua XXV. Husserl, E. (1987): Aufsätze und Vorträge. (1911-1921). T. Nenon, \& H. R. Sepp (Eds.). Dordrecht: Nijhoff.

Hua XXX. Husserl, E. (1996): Logik und allgemeine Wissenschaftstheorie. U. Panzer (Ed.). Dordrecht: Kluwer.

Huemer, M. (2001). Skepticism and the veil of perception. Lanham, MD: Rowman \& Littlefield.

Huemer, M. (2005). Ethical intuitionism. Houmills \& Basingstoke: Palgrave Macmillan.

Huemer, M. (2007). Compassionate phenomenal conservatism. Philosophy and Phenomenological Research, LXXIV/1, 30-55.

Huemer, M. (2013). Phenomenal conservatism über alles. In Ch. Tucker (Ed.), Seemings and Justification. New essays on dogmatism and phenomenal conservatism (pp. 328-350). Oxford: Oxford University Press.

Koksvik, O. (2011). Intuition. Ph.D. Thesis, Australian National University.

Luft, S. (2004). Husserl's theory of the phenomenological reduction: Between life-world and cartesianism. Research in Phenomenology, 34, 198-234.

Lycan, W. (2013). Phenomenal conservatism and the principle of credulity. In C. Tucker (Ed.), Seemings and justification. New essays on dogmatism and phenomenal conservatism (pp. 293-305). Oxford \& New York: Oxford University Press.

Madary, M. (2016). Visual Phenomenology. Cambridge: The MIT Press.

Markie, P. (2005). The mystery of direct perceptual justification. Philosophical Studies, 126, 347-373.

Pryor, J. (2004). What's wrong with Moore's Argument? Philosophical Issues, 14, 349-378.

Pryor, J. (2013). Problems for credulism. In C. Tucker (Ed.), Seemings and justification. New essays on dogmatism and phenomenal conservatism (pp. 89-131). Oxford \& New York: Oxford University Press.

Rinofner-Kreidl, S. (2013). Mental contents, transparency, realism: News from the phenomenological camp. Husserl Studies, 29, 33-50.

Rinofner-Kreidl, S. (2014). Phenomenological intuitionism and its psychiatric impact. In T. Fuchs, T. Beyer, \& C. Mundt (Eds.), Karl Jaspers' philosophy and psychopathology (pp. 33-60). New York: Springer.

Rinofner-Kreidl, S. (2015). Mereological foundation vs. supervenience? A Husserlian proposal to re-think moral supervenience in Robert Audi's ethical intuitionism. Metodo. International Studies in Phenomenology and Philosophy, 3/2, 81-124.

Siegel, S. (2016). The contents of perception. The Stanford Encyclopedia of Philosophy (Spring 2016 Edition), Edward N. Zalta (Ed.). URL=<http://plato.stanford.edu/archives/spr2016/entries/ perception-contents/>.

Silins, N. (2014). Experience does justify belief. In R. Neta (Ed.), Current controversies in epistemology (pp. 55-69). New York \& London: Routledge.

Smithies, D. (2014). The phenomenal basis of epistemic justification. In M. Sprevak \& J. Kallestrup (Eds.), New waves in philosophy of mind (pp. 98-124). New York: Palgrave Macmillan.

Soteriou, M. (2016). The disjunctive theory of perception. The Stanford Encyclopedia of Philosophy (Summer 2016 Edition), Edward N. Zalta (Ed.). URL=<http://plato.stanford.edu/archives/sum2016/ entries/perception-disjunctive/>.

Tolhurst, W. (1998). Seemings. American Philosophical Quarterly, 35(3), 293-302.

Tucker, Ch. (2010). Why open-minded people should endorse dogmatism. Philosophical Perspectives, 24, 529-545.

Tucker, C. (2013). Seemings and justification: An introduction. In C. Tucker (Ed.), Seemings and justification. New essays on dogmatism and phenomenal conservatism (pp. 1-29). Oxford: Oxford University Press.

Tye, M. (2015). Qualia. The Stanford Encyclopedia of Philosophy (Fall 2015 Edition), Edward N. Zalta (Ed.). URL=<http://plato.stanford.edu/archives/fall2015/entries/qualia/ $>$.

Wiltsche, H. (2015). Intuitions, seemings, and phenomenology. Teorema XXXIV/3: 57-77. 